Conventional university discipline, communal meals, and times for visitors, will be impracticable in the new building. And it will be interesting to see how students take to living together in such large groups. The social and financial implications of the scheme will be discussed by a sub-committee of the Committee of Vice-Chancellors, in order that other universities may be informed of Lancaster's experiment.

\section{Post Office Computers}

After the haste with which the Post Office (Data Processing Service) Bill went through Parliament, the service seems to be taking some time to get down to work. The service is being planned by the General Post Office Computer Development Department, whose director is Mr C. R. Smith. Although computer time will be offered for sale almost immediately, the data processing service is not expected to become fully operational for about two years.

At present the Post Office has computer centres in London, Derby, Portsmouth, Edinburgh and Lytham St Annes, with computer equipment worth $£ 4$ million already installed and working. It plans to set up further centres at Bootle, Leeds, Glasgow, Bristol and Manchester. The cost of setting up this service is expected to be about $£ 12$ million. By 1971 the Post Office hopes to have twenty large computers in operation up and down the country, all linked together.

The computers will be primarily for the use of the Post Office - the Bootle centre, for example, will work with the Giro banking system, but as part of the service the Post Office will sell off surplus time. Twelve of the GPO computers are English ElectricElliott and one is made by ICT. There are further English Electric-Elliott computers on order.

\section{Computers for Columbia}

A schene for permitting access to the computers being used at Columbia University from the offices of individuals making use of them is to be carried out by 1969. Altogether, the university is planning to spend $\$ 3$ million on the provision of 200 access points scattered around the Columbia campuses. The intention is to allow individual researchers to communicate directly with the whole of the computer system at Columbia. It has been calculated by those responsible for the development of the new system that the provision of several access points will increase five-fold the present power of the computers already installed at Columbia.

Apparently the planners are thinking simply of the extension of the present uses of the computer centre at Columbia, which has in the past four years grown so that it handles an average of between 6 and 7 million jobs each day. One advantage of providing multiple access to the computing network is that it will be easier for demands for small blocks of computer time to be met. In practice, it appears that the computer centre at Columbia tends to accumulate throughout each week a backlog of work which is cleared at the weekend. The network of access points now being provided is intended simply to help with the management of the computers' time. The system differs, of course, from true multiple access systems in which several jobs are processed more or less simultaneously.

\section{Air Fares Go Up}

From September, air fares in Britain are to rise between 11 and 15 per cent. The Air Transport Licensing Board last approved an increase of fares in April 1966 so that this second fare rise within eighteen months has caused a certain amount of comment.

Comparisons are often made between the costs of travelling between London and Glasgow, and between San Francisco and Los Angeles: the British trip costs 7.49 cents per mile, the American only 3.96 cents. But San Francisco and Los Angeles are two poles of population density in a way in which London and Glasgow are not. A better comparison could be made with the New York-Pittsburgh route, on which passengers are travelling between a huge metropolis and one of a number of large industrial cities in a densely populated region. The cost of this journey, of length similar to the other two, is 6.87 cents per mile; and it is interesting to note that the sector is served by two carriers, one of which, Allegheny Airlines, is subsidized by the Federal Government. Pilot salaries are, of course, higher in the United States, but airport charges are heavy in Britain-the first thirty passengers on a Vanguard flight between Manchester and London pay for the airport charges, according to BEA. Air fares in Europe are often more expensive than in Britain, so that the new increases may well have been unavoidable.

Yet even if fares are relatively low, it is impossible to say how far the size of the increase is justified. This is because, although the Licensing Board has access to the accounts of the various airlines, it is not permitted to make them public. Private individuals have no right to object to the raising of fares, but the board sometimes allows them to make statements, especially if they represent groups of people likely to be affected by changes in fares. These individuals are then allowed to "cross-examine" the airlines; the airlines do not, however, have to reply.

Clearly the Licensing Board is unhappy with the situation. In its report on its decision to raise fares, the board says: "It is unfortunate that the powers under which it (the information on which the decision rests) was obtained do not allow us to make this information public. ... We think that a general disclosure of such information would be beneficial to British aviation .

\section{More Scientists as Astronauts}

Among the new NASA intake of 11 scientist-astronauts there is a Welsh chemist and an Australian physicist. The inclusion of these two naturalized American citizens breaks new ground for the American programme -indeed the Australian, Dr Philip Chapman, only gained his US citizenship this May though he has been working at the Experimental Astronomy Laboratory of MIT since 1961. The Welshness of Dr John Llewellyn -despite 9 years' work in North America-is not to be concealed; besides his own good Welsh name his wife was born Valerie Davies-Jones and his 3 children rejoice in the names Gareth, Sian and Ceri Elummed. Both naturalized astronauts have gravitated to their present appointments by way of Canada. The acceptance by NASA of naturalized citizens for their sensitive manned space programme reflects the new emphasis on appropriate scientific background for the second generation of manned space operations 